be subject to irregularity in division, for gametes arise (as in tetraploid Prunus cerasus and Tradescantia virginiana) both with more and less than the normal gametic number, and the fertility of such tetraploids is consequently reduced.

We may mention parenthetically that, just as the functional gametes must contain two out of the four chromosomes of each type chosen at random, so the breeding results in tetraploid Datura and Primula sinensis have always agreed with the assumption that two Mendelian factors, chosen at random from four, pass to each gamete. This agreement, verifying prediction, is a substantial corroboration of the chromosome theory of heredity.

On the other hand, we have tetraploids arising as a result of doubling in hybrids. The result depends on what we may loosely call the 'degree of hybridity.' Primula kewensis is not an extreme example, and will serve to show the peculiarities

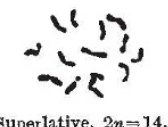

Superlative, $2 n=14$

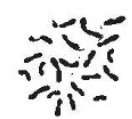

Mahdi, $2 n=21$.

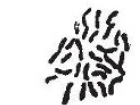

Veitchberry, $2 n=28$.

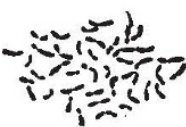

Loganberry, $2 n=42$
Laxtonberry $2 n=49$.

FIG. 4.-Diploid and polyploid species and varieties of Rubus. Al the even multiples are fertile, although the tetraploid and hexaploid are known to be interspecific hybrids. The odd multiples are both sterile in a high degree.

associated with various degrees of hybridity. It is the result of a cross between Primula floribunda and by $P$. verticillata, which gave in the first instance a sterile intermediate diploid hybrid, as might have been expected. This diploid produced a giant fertile shoot the offspring of which were fairly constant, giant, and fertile like itself. This shoot was tetraploid and must have arisen as a result of the formation of tetraploid somatic cells, as in Solanum. In the diploid hybrid, the corresponding chromosomes of the two parental species paired at reduction ; its sterility must therefore be assumed to be the result of failure of the new genetic combinations brought together in the gametes. In the tetraploid, however, pairs are usually formed as in the diploid, but the general absence of segregation means that identical mates must pair and pass to opposite gametes.

This conclusion is justified by the fact that a small proportion of segregates is produced bearing certain characters of the parental species, that is, no longer intermediate in every respect. In a similar small proportion of cases the chromosomes associate in fours, derived therefore from both species and capable of yielding gametes pure in the characters of one species carried by the chromosomes concerned. It follows that the constancy and relative fertility of the hybrid tetraploid depends on its degree of hybridity, for, in so far as the corresponding chromosomes of the opposite species are capable of pairing in the tetraploid derivative, dissimilar gametes will be produced, both as a result of genetic segregation and abnormality in the division of quadrivalents. In both cases fertility is reduced.

These remarks, which are based on theoretical considerations, are in agreement with all the available experimental evidence. Fertile diploids such as Enothera Lamarckiana, Datura Stramonium, Primula sinensis, Solanum Lycopersicum, and Campanula persicifolia give less fertile tetraploids. Sterile diploids such as Primula kewensis, RaphanusBrassica, and relatively diploid Nicotiana and Solanum hybrids give more fertile tetraploids.

It is therefore possible for a tetraploid arising from a hybrid diploid to have the mechanical properties of a fertile diploid. But it combines with these certain genetical peculiarities. Not only is it a hybrid, with such physiological advantages as hybridity may confer, but occasionally the corresponding chromosomes of the opposite diploid parents may pair. The tetraploid will then show the segregation of a hybrid, and may give rise to offspring with any workable combination of the characters of its two parents.

(To be continued.)

\title{
Obituary.
}

Prof. R. J. Harvey-Gibson.

THE death in Glasgow on June 3, at sixty-nine 1 years of age, of Dr. Robert J. Harvey-Gibson, emeritus professor of botany in the University of Liverpool, will be widely regretted. Prof. HarveyGibson was a son of the manse and was educated in the Universities of Aberdeen, Edinburgh, and Strasbourg. He first held appointments as demonstrator in zoology and later in physiology in the University of Edinburgh. His association with the University of Liverpool goes back to the year 1883, in which his first appointment was that of demonstrator in biology in the old School of Medicine, which was later amalgamated with University College as the foundation of the present University.
At the amalgamation, Harvey-Gibson was promoted to a lectureship in botany, which became in 1887 a subject in the new Faculty of Science. The institution and growth of a Department of Botany under his direction soon followed, and in 1889 a new laboratory was erected to meet the needs of the Department. The first assistant in the Department was Dr. A. J. Ewart, and when in 1894 Mr. Holbrook Gaskell made possible the foundation of a chair of botany, Harvey-Gibson became its first holder and worked arduously for the advancement of the Department and the acquisition of modern laboratories. At that time Dr. J. C. Willis was a student in the Department. In $1900 \mathrm{Mr}$. Hartley offered to build a new laboratory, and in 1902 the present Department was erected to the plans of 
Prof. Harvey-Gibson, and was officially opened by Sir W. Thiselton-Dyer.

It may truly be said that Harvey-Gibson devoted himself to the construction and equipment of a department, and that in this he built largely for his successors. Yet he found time for investigation and writing on varied subjects, for he was of catholic interests, and for administration in many fields of University activity. His chief contributions to his subject are a series of papers on marine algæ, the Lycopods, and on questions of systematic anatomy, and he was the author of philosophical essays, an outline of the history of botany, and other works of a more general nature. He was keenly interested in the military training of undergraduates and was the founder of the Officers' Training Corps of his University. During the War he served as a colonel in the Territorial Army and took an active part in the work of the Red Cross Society.

Harvey-Gibson was a man of scholarly achievement, and although he had been in indifferent health for some years, he maintained a lively interest in all branches of his subject and in classical study.

\section{Mrs. Theodore Bent.}

Tre death of Mrs. Theodore Bent on July 3, at the age of eighty-three years, has removed a striking personality for many years familiar in literary and scientific circles in London. She was the widow of Theodore Bent, whom she married in 1877. Of Irish extraction, she preserved to the end of her life some of the characteristics of her nationality, notably readiness in conversation and a sharpness in repartee.

Mrs. Bent accompanied her husband and gave him valuable assistance in his many journeys of archæological exploration. Their first important expedition was in the Aegean Islands in 1885-86 and 1886-87. In the latter year Bent was excavating in Thasos under the auspices of the Society for the Promotion of Hellenic Studies. Journeys to Asia Minor in 1888 and to the Bahrein Islands in the Persian Gulf in 1889 were followed by their bestknown expedition in 1891, when they visited South Africa to study the ancient ruins at Zimbabwe in Mashonaland, then examined and measured systematically for the first time. The results of the expedition were embodied in "The Ruined Cities of Mashonaland" which appeared in 1892. Bent held the view that the builders of Zimbabwe were a northern race from Arabia, and for the rest of his life-he died in 1897-their expeditions had as their object to discover traces of such a race. They visited Abyssinia and the southern part of Arabia, of which they made a special study, visiting the almost unknown Hadramut country. Their last journey was through the Vafei and Fadhli countries in March 1897, Mrs. Bent giving an account of this journey to the Royal Geographical Society.

Mrs. Bent was an experienced photographer, as well as an accurate observer, as was shown by the book "Southern Arabia", published in 1900, which was written mainly by her with the aid of her husband's journals. One book which she wrote apart from her husband was "Anglo-Saxons from Palestine", published in 1900, in which she showed herself an adherent of the Anglo-Israelite theory.

WE regret to announce the following deaths:

Mr. A. B. Bruce, formerly of the Indian Civil Service and of the Ministry of Agriculture, on July 2. Prof. L. T. Hobhouse, Martin White professor of sociology in the University of London, on June 21, aged sixty-four years.

\section{News and Views.}

AN honorary fellowship of the British Academy-a signal distinction-has been added to the many academic honours which have been conferred on that veteran scholar, Prof. A. H. Sayce. He has also been awarded the Huxley Memorial Medal of the Royal Anthropological Institute for 1929, and invited to deliver the Institute's Huxley Memorial Lecture in 1930. Prof. Sayce's long career-he is now in his eighty-fourth year, and has been a fellow of Queen's College, Oxford, since 1869-is a remarkable record of scholarship, both in the study and in the field. For to the long list of books and articles from his pen dealing with the archæology of the Near East, especially as related to Biblical archæology, must be added his work as an explorer and excavator in Asia Minor, Egypt, and other countries of the East which bear upon his special studies. His work in the decipherment of cuneiform and Hittite inseriptions will always be a monument to British scholarship in this branch of study. Yet notwithstanding the highly specialised character of his studies, his interests have always remained wide, as was shown by the "Reminiscences" published in 1923. It was probably a surprise to most of his readers to learn that he was nearly shot as a spy in the Franco-Prussian War of 1870.

The Kelvin Medal Award Committee, consisting of the presidents of the leading British engineering institutions, after consideration of representations received from leading engineering bodies in all parts of the world, has awarded the Kelvin Medal for 1929 to M. André Blondel. The medal is awarded as a mark of distinction in engineering work and investigation of the kinds with which Lord Kelvin was especially identified. M. Blondel, as engineer of the Ponts et Chaussées since 1889 and for many years the chief engineer of the French lighthouse services, is distinguished by his work on signalling apparatus, both optical and electrical, and particularly for his investigations in connexion with electrical measuring apparatus and photometry. In 1913 he was elected a member of the Paris Academy of Sciences, and in 1923 was appointed Inspecteur Général des Ponts et Chaussées. M. Blondel is an honorary member of both the British and American Institutions of Electrical Engineers. This is the fourth triennial award

No. 3115, VoL. 124] 